\title{
Idiopathic Hypogonadotropic Hypogonadism Caused by Inactivating Mutations in SRA1
}

\author{
Leman Damla Kotan1, Charlton Cooper2, Şükran Darcan3, Ian M. Carr4, Samim Özen3, Yi Yan2, \\ Mohammad K. Hamedani2, Fatih Gürbüz1, Eda Mengen1, Ihsan Turan1, Ayça Ulubay5, Gamze Akkuş6, \\ Bilgin Yüksel1, A. Kemal Topaloğlu1, Etienne Leygue² \\ ${ }^{1}$ Çukurova University Faculty of Medicine, Department of Pediatrics, Division of Pediatric Endocrinology, Adana, Turkey \\ 2 University of Manitoba, Manitoba Institute of Cell Biology, Winnipeg, Manitoba, Canada \\ ${ }^{3}$ Ege University Faculty of Medicine, Department of Pediatrics, Division of Pediatric Endocrinology, Izmir, Turkey \\ 4 University of Leeds, Institute of Biomedical and Clinical Sciences, Section of Genetics, Leeds, United Kingdom \\ ${ }^{5}$ Çukurova University Faculty of Medicine, Department of Forensic Medicine, Adana, Turkey \\ ${ }^{6}$ Çukurova University Faculty of Medicine, Division of Endocrinology and Metabolism, Adana, Turkey
}

\section{WHAT IS ALREADY KNOWN ON THIS TOPIC?}

Pubertal development is thought to be a result of a complex interplay among genes and environmental factors including nutrition.

\section{WHAT THIS STUDY ADDS?}

$S R A$ I gene function is required for the initiation of puberty in humans.

\section{ABSTRACT}

Objective: What initiates the pubertal process in humans and other mammals is still unknown. We hypothesized that gene(s) taking roles in triggering human puberty may be identified by studying a cohort of idiopathic hypogonadotropic hypogonadism (IHH).

Methods: A cohort of $\mathrm{IHH}$ cases was studied based on autozygosity mapping coupled with whole exome sequencing.

Results: Our studies revealed three independent families in which $\mathrm{IHH} /$ delayed puberty is associated with inactivating SRA1 variants. SRA1 was the first gene to be identified to function through its protein as well as noncoding functional ribonucleic acid products. These products act as co-regulators of nuclear receptors including sex steroid receptors as well as SF-1 and $L R H-1$, the master regulators of steroidogenesis. Functional studies with a mutant $S R A 1$ construct showed a reduced co-activation of ligand-dependent activity of the estrogen receptor alpha, as assessed by luciferase reporter assay in HeLa cells.

Conclusion: Our findings strongly suggest that $S R A 1$ gene function is required for initiation of puberty in humans. Furthermore, SRA1 with its alternative products and functionality may provide a potential explanation for the versatility and complexity of the pubertal process.

Keywords: Hypogonadotropic hypogonadism, puberty, SRA1, PNPLA6, mutation

Conflict of interest: None declared

Received: 07.04.2016

Accepted: 09.04 .2016 


\section{Introduction}

What initiates the pubertal process in humans and other mammals is still an enigmatic question (1). The hallmark of puberty is reemergence of a pulsatile gonadotropin-releasing hormone $(\mathrm{GnRH})$ release from the hypothalamus driving the pituitary gonadotropes to secrete luteinizing hormone $(\mathrm{LH})$ and folliclestimulating hormone (FSH), which act in concert to stimulate the gonads to bring about sex hormone secretion and gametogenesis. Normosmic idiopathic hypogonadotropic hypogonadism $(\mathrm{IHH})$ is characterized by failure to develop secondary sexual characteristics and a mature reproductive system due to defects in the central part of the hypothalamo-pituitary-gonadal axis. In an effort to gain a greater understanding into the elusive pubertal process, our laboratory has undertaken a search for genes playing important roles in the generation of gonadotropin secretion in a cohort of familial IHH cases via autozygosity mapping. Our previous seminal descriptions of the mutated genes, TAC3, TACR3 (2), and KISS1 (3) in this same patient cohort led the way to the characterization of the $\mathrm{GnRH}$ pulse generator (4). Along the same line, we hypothesize that gene(s), whose products trigger the $\mathrm{GnRH}$ pulse generator to restart ticking at the usual time of puberty, can also be identified via autozygosity mapping together with whole exome sequencing.

\section{Methods}

As an overall genetic sequencing strategy, we screen probands from consanguineous multiplex pedigrees for known $\mathrm{IHH}$ genes in our $\mathrm{IHH}$ cohort. If no mutation is found, then we perform autozygosity mapping based on either single nucleotide polymorphism (SNP) microarray genotyping or (lately) whole exome sequencing. Once we identify a likely candidate gene, we then screen the probands for that gene in the entire cohort either with Sanger sequencing or whole exome sequencing.

\section{Case Reports}

\section{Family 1}

The proband (II-2), a 25-year-old male, grew and developed normally until his early-to-mid-teen years. At the age of 15 , he presented with a chief complaint of absent pubertal development. His past medical history was remarkable for undescended testicles, for which he received human chorionic gonadotropin treatment. His testicular volumes were $3 \mathrm{~mL}$ bilaterally. His basal and stimulated gonadotropin levels as well as testosterone concentrations remained prepubertal.

The affected sibling (II-1) is a 30-year-old female. She grew and developed normally until her early-to-mid-teen years. At the age of 15, she presented with absent breast development and lack of menses. She had Tanner stage 1 breast development and stage 2 axillary and pubic hair. Her bone age then was 13 years. A pelvic ultrasonography showed a hypoplastic uterus and ovaries.

The parents are healthy and paternal cousins of Turkish origin. The mother experienced menarche at age 12 years, and the father started shaving at age 14 years.

\section{Family 2}

The proband (II-3), now an 18-year-old man, first presented to us at age 13 years with a small penis for which he had been given some human menopausal gonadotropin injections elsewhere. His past medical history was remarkable for undescended testicles and inguinal hernia. At age 14, his testicular volumes were $3 \mathrm{~mL}$ bilaterally, with stretched penile length of $4 \mathrm{~cm}$. While having a bone age of 13 , his gonadotropin and testosterone levels were prepubertal. Shortly afterwards, his testicular volumes increased to pubertal levels with corresponding penile growth and pubertal hormone levels. Both of his sisters have gone through puberty in time.

The parents are healthy, unrelated, and of Turkish origin. The mother experienced menarche at age 12 years, and the father started shaving at age 14 years.

\section{Family 3}

The proband (II-3) is a 21-year-old male, who grew and developed normally until his early-to-mid-teen years. At the age of 16 , he presented with absent pubertal development. His past medical history was unremarkable. His testicular volumes were $2 \mathrm{~mL}$ bilaterally. His bone age was 12 years at presentation. His basal and stimulated gonadotropin levels as well as testosterone concentrations remained prepubertal.

The affected sibling (II-4) is a 17-year-old male. He grew and developed normally until his early-to-mid-teen years. At the age of 12.5 years, he presented with absent pubertal development. His past medical history was remarkable for a small penis and undescended testicles for which he received human chorionic gonadotropin treatment and subsequent orchiopexia at age 4 . His right testicle was reportedly not found at the intervention. His bone age was 11.5 years at presentation to us. Later at age 14 years, he has spontaneously started pubertal development to become a young adult with normal hormonal values.

The parents are healthy, unrelated, and of Kurdish origin. The mother experienced menarche at age 12.5 years, and the father started shaving at age 13.5 years.

The clinical and hormonal features of the affected individuals in the three families are shown in Table 1.

The pedigrees of the families are shown along with their genotypes in Figure 1. The patients are otherwise healthy and have a normal sense of smell. They have otherwise normal anterior pituitary functions. In consideration of the known roles of the SRA1 with other nuclear receptors, any disorders associated with a potential dysfunction of these receptors were actively ruled out. Thus, thyroid receptor was ruled out 



Figure 1. Pedigree profile and corresponding SRA1 and PNPLA6 mutations in the three families. Pedigrees are shown to indicate phenotypes and genotypes among family members. Filled circles indicate affected girls or women, open circles unaffected female family members, filled squares affected male family members, and open squares unaffected male family members. The double line indicates consanguinity. Under each available individual is the SRA1 and PNPLA6 gene genotype with $\mathrm{M}$ indicating mutant and WT indicating wild type by normal thyroid function test, PPAR $\gamma$ by normal fasting blood glucose and Hemoglobin A1c, corticosteroid receptors by normal 8 AM cortisol and adrenocorticotropic hormone (ACTH) levels, retinoid receptors by direct examination of the retina by an ophthalmologist, and dilated cardiomyopathy due to abnormal myogenesis by echocardiography and a cardiological examination.

The Ethics Committee of the Çukurova University Faculty of Medicine approved this study, and informed consent was obtained from each participant or from the parents.

Hormonal measurements in the affected individuals: Plasma ACTH, serum LH, FSH, estradiol, dehydroepiandrosterone sulfate, cortisol, and testosterone levels were analyzed by commercial kits based on solidphase, two-site sequential, or competitive chemiluminescent immunometric assay (Beckman Coulter).

A $\mathrm{GnRH}$ stimulation test was performed on the proband of the Family 1 by injecting $0.1 \mathrm{mg} \mathrm{GnRH}$ intravenously and drawing blood samples at $0,15,30,45,60$, and 75 minutes for FSH and LH determinations.

A prolonged $\mathrm{GnRH}$ stimulation test was also performed on the proband of the Family 1. A daily subcutaneous injection of $\mathrm{GnRH}$ at $0.1 \mathrm{mg}$ for one week was administered and on the $7^{\text {th }}$ day, plasma FSH and LH levels were determined 30, 45, and 60 minutes after the injection.

Table 1. The clinical and hormonal features of the affected individuals in the three families

\begin{tabular}{|c|c|c|c|c|c|c|}
\hline \multirow[b]{2}{*}{ Family member } & \multicolumn{2}{|c|}{ Family 1} & \multirow{2}{*}{$\begin{array}{l}\text { Family } 2 \\
\text { II-3 }\end{array}$} & \multicolumn{2}{|c|}{ Family 3} & \multirow[t]{2}{*}{ Normal range } \\
\hline & II-2 & II-1 & & II-3 & II-4 & \\
\hline Gender & $\mathrm{M}$ & $\mathrm{F}$ & $\mathrm{M}$ & $\mathrm{M}$ & $\mathrm{M}$ & \\
\hline $\mathrm{FSH}(\mathrm{mlU} / \mathrm{mL})$ & $<1.8$ & $<1.8$ & 1.0 & 0.94 & 2.4 & $\begin{array}{l}\text { M: } 1.4-18.1 \\
F: 2.5-10.2\end{array}$ \\
\hline $\mathrm{LH}(\mathrm{mlU} / \mathrm{mL})$ & $<0.7$ & $<0.7$ & 0.1 & 0.3 & 0.8 & $\begin{array}{l}\text { M: } 1.5-9.3 \\
\text { F: } 1.9-12.5\end{array}$ \\
\hline Estradiol (ng/dL) & ND & $<20.0$ & ND & ND & ND & $\begin{array}{l}\text { M: 0.8-3.5 } \\
\text { F: } 6.3-16.5\end{array}$ \\
\hline Testosterone (ng/dL) & 20.0 & ND & 16.0 & 26.0 & 24.5 & $175-781$ \\
\hline Prolactin (pg/mL) & 18.0 & 9.4 & 6.6 & 6.8 & ND & $\begin{array}{l}\text { M: } 2.1-17.7 \\
\text { F: } 2.8-29.2\end{array}$ \\
\hline TSH (mIU/mL) & 1.1 & 2.0 & 2.1 & 2.3 & 3.9 & $0.35-4.2$ \\
\hline Free $T_{4}(\mathrm{ng} / \mathrm{dL})$ & 1.1 & 1.1 & 1.2 & 0.9 & 0.7 & $0.89-1.8$ \\
\hline Cortisol (mcg/dL) & 21.0 & 9.5 & ND & 14.3 & ND & $3-25$ \\
\hline LHRH stimulation test (max. LH) & $<0.7$ & $<0.7$ & ND & 4.1 & ND & $\begin{array}{l}\text { M: } 1.5-9.3 \\
\text { F: } 1.9-12.5\end{array}$ \\
\hline LHRH stimulation test (max. FSH) & 0.7 & 3.5 & ND & 4.4 & ND & $\begin{array}{l}\text { M: } 1.4-18.1 \\
F: 2.5-10.2\end{array}$ \\
\hline
\end{tabular}

M: male, F: female, FSH: follicle-stimulating hormone, LH: luteinizing hormone, TSH: thyroid-stimulating hormone, $\mathrm{T}_{4}$ : thyroxine, LHRH: luteinizing hormone-releasing hormone, ND: not determined 
Screening of known genes by Sanger sequencing: Known or strong candidate genes for $\mathrm{HH}$ and Kallmann syndrome including GNRHR, GNRH1, LHB, FSHB, KISS1R, KISS1, TAC3, TACR3, KAL1, PROK2, PROK2R, and FGFR1 were screened by automated Sanger sequencing (5). Briefly, polymerase chain reaction-amplified exons and splice junctions were sequenced on an ABI PRISM 3130 autosequencer (Applied Biosystems)

Genome-wide single nucleotide polymorphism analysis: For genome-wide SNP analysis, we used $250 \mathrm{~K}$ Nspl SNP microarrays (Affymetrix) and analyzed data using AutoSNPa software (AutoSNPa.org) to identify autozygous regions in Family 1.

Whole exome sequencing: Samples were prepared as an Illumina sequencing library, and in the second step, the sequencing libraries were enriched for the desired target using the Illumina Exome Enrichment protocol. The captured libraries were sequenced using Illumina HiSeq 2000 Sequencer (Macrogen, Seoul, Korea). The reads are mapped against UCSC hg19.

Site-directed mutagenesis: SRA-D7 and SRAWT constructs were previously described (6). SRA-Y35N was generated using synthetic oligonucleotides and the QuickChangell site directed mutagenesis kit (Agilent Technologies) using SRA-WT vector as template following manufacturer's protocol.

Western Blot and immunofluorescent microscopy: Western Blot and Immunofluorescent Microscopy were performed as previously described (7).

Luciferase assay: Twenty-four hours prior to transfection, HeLa cells were seeded into 24 well dishes (7.5x105 cells/ well) containing $5 \%$ CS-FBS phenol-red free DMEM containing $4.5 \mathrm{~g} / \mathrm{L}$ D-glucose and $2 \mathrm{mM}$ L-glutamine. Cells were then co-transfected with constructs expressing PS2-ERE (0.4 ug), ERa (0.04 ug), Renilla (0.02 ug), and various SRA (0.34 ug) using Lipofectamine 2000 (Life Technologies) according to the manufacturer's protocol. The next day, the medium was changed and replaced with 5\% CS-FBS DMEM containing either ethanol vehicle (cont-E) or $10 \mathrm{nM}$ beta-estradiol [+E (Sigma)] for an additional 24 hours before lysis in $100 \mathrm{uL} 1 \mathrm{xPLB}$ buffer (Promega). Renilla luciferase and luciferase activities were measured using SpectraMaxL Luminometer (Molecular Devices) and SoftMax Pro software using Dual Luciferase Reporter Assay System (Promega) reagents according to the manufacturer's instructions. For each constructs, readings were normalized to control. Results represent the average of four independent experiments performed in triplicate.

\section{Statistical Analysis}

HeLa cell transfected with SRA-WT and mutant constructs were compared to control cells transfected with SRA-D7 construct in the absence or presence of estradiol using unpaired 2-tail student's t-test. Graphpad prism 5 software was used for all statistical analyses.

\section{Results}

Hormonal results as shown in Table 1 are consistent with the diagnosis of $\mathrm{IHH}$.

Family 1: A genome-wide SNP analysis identified two regions of homozygosity common to the affected siblings but not found in the parents. Two autozygous regions spanned on chromosome 2 from 132159998 to 142605624 and on chromosome 5 from 107034345 to 161513613 . Analysis of targeted exome sequencing data for the autozygous regions revealed that the only plausible candidate variant to account for the phenotype is in the SRA1 gene. A subsequent whole exome sequencing data on the proband were analyzed with particular attention to these autozygous regions by filtering for homozygous variants that are in the coding or splice regions and of minor allele frequency less than $1 \%$ or previously undescribed. Our analyses singled out a missense mutation in the SRA1 gene in the larger autozygous region on chromosome 5 . We confirmed the presence of this nonsynonymous mutation in the coding sequence of SRA1 gene (HGNC: 11281) in the proband (Figure 2) by Sanger sequencing. The proband and his affected sibling were homozygous for a T-to-A change at cDNA nucleotide 103 (NM_ 001035235.3: c.T103A), leading to the substitution of tyrosine at residue 35 for asparagine (NP_001030312.2: p.Y35N). Their parents both were heterozygous for this mutation. Y35 is among phosphorylated residues. SIFT predicts that this substitution would affect the protein function with a score of 0.00 and PolyPhen-2 predicted this variant probably damaging. In addition, this variant was neither found in 100 ethnically matched healthy adult controls, 110 in-house whole exomes, nor in 1000 genomes, Exome Variant Server or in the ExAC databases. Besides, this variant was not seen in the Turkish


Figure 2. Results of automated DNA sequencing for SRA1 mutations in the three families. Top, middle, and bottom pictures show mutations in Family 1, 2, and 3, respectively. In Family 1 picture, top, middle, and bottom lines indicate wild type, heterozygous, and homozygous mutations, respectively. In Families 2 and 3 pictures, top and bottom lines indicate wild type and heterozygous mutations, respectively. In addition, the PNPLA6 mutation in Family 3 is also shown in the same order 
whole exome database consisting of over 1000 Individuals' data at TÜBITAK-BILGEM. Genotyping by Sanger screening and/or whole exome sequencing in search of additional SRA1 mutations in $136 \mathrm{IHH}$ families revealed two other families with SRA1 mutations. In view of the co-occurrence of a PNPLA6 mutation in family 3 , we thoroughly screened the affected individuals in family 1 and 2 for PNPLA6 mutations by Sanger sequencing and did not find any suspicious variants.

Family 2: A whole exome sequencing in the proband revealed two heterozygous variants: a C-to-G change at CDNA 94 predicting substitution of glutamine at residue 32 for glutamic acid, p.Q32E, rs35610885 and a T-to-C change at cDNA 536 predicting substitution of isoleucine at residue 179 for threonine, p.I179T, rs14810885 (Figure 2). Both of these variant were predicted to be harmful by SIFT and PolyPhen-2. In addition, these variants were not found in 100 ethnically matched healthy adult controls, 110 in-house exomes, or in 1000 genomes, or Exome Variant Server. The allele frequency rates of the p.Q32E and an in p.I179T variants are 0.007 and 0.0007 in ExAC; the allele frequency rates in Turkish whole exome database were 0.004 and 0.006 , respectively.

Family 3: A Sanger screening for SRA1 showed that the proband and his affected brother had a heterozygous mutations (a C-to-T change at cDNA 59 predicting substitution of proline at residue 20 for leucine, p.P20L) (Figure 2). This variant was predicted to be harmful by both SIFT and PolyPhen-2. A whole exome sequencing in the proband revealed a heterozygous variant in PNPLA6 (HGNC: 16268, NM_006702; a c.C1742G leading to p.T581R) in both siblings (Figure 2) in addition to confirming the SRA1 variant described above. As can be seen in the pedigrees, the $\mathrm{IHH}$ phenotype segregated with co-occurrence of these two heterozygous mutations in the nuclear family, except for the eldest sibling who appears to be unaffected but carries the two variants. The whole exome sequencing in the proband showed no other mutations in known $\mathrm{IHH}$ genes. In addition, these variants were neither found in 100 ethnically matched healthy adult controls, 110 in-house exomes, 1000 genomes, or Exome Variant Server. The PNPLA6 variant was seen once in the ExAC while none in Turkish whole exome database respectively. The SRA1 variant is seen in 12 (allele frequency <1/1000-10.000) and once in the ExAC and Turkish whole exome database, respectively.

None of the probands from those three families harbored mutations in known $\mathrm{IHH}$ and Kallmann genes (5).

Highly conserved positions of the mutations in the ribonucleic acid (RNA) and protein products of SRA1 are shown in Figure 3.

\section{Y35N Mutation Impairs SRA Mediated Estrogen Receptor Alpha (ESR1)Transactivation}

SRA1 gene products are known to potentiate liganddependent transcription of several nuclear receptor transcription factors as measured by response-element driven luciferase activity under standard luciferase reporter assay conditions
$(6,8,9,10,11)$. In particular, SRA has been shown to co-activate estradiol-induced estrogen receptor alpha (ESR1) transcription of luciferase reporters whose expression is under control of the estrogen-response-elements derived from the PS2 gene (PS2-ERE) $(6,9,10)$. We have addressed whether the mutant found in family 1 (SRA-Y35N) could differentially co-regulated estrogen-dependent ER-alpha activity compared to wild-type SRA (SRA-WT). HeLa cells were co-transfected with an EREluciferase, ER-alpha, and either SRA-WT, SRA-Y35N, or SRAMET7 control construct. This control corresponds to an artificial SRA sequence unable to encode functional SRA RNA due to extensive silent mutations at codon wobble positions, nor SRA protein (SRAP) as a result of site-directed conversion of all SRA methionine residues to leucines $(6,12)$. Cell were subsequently treated with estradiol (+E2) or ethanol (cont) as described in the Material and Methods section.

We checked that SRA-WT and mutant SRA-Y35N levels reached in these experiments were similar. As shown in Figure 4A, Western blot analysis of protein extracts from cells transfected with either SRA-WT or SRA-Y35N showed
$\mathbf{A}$
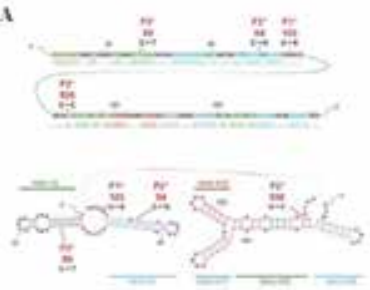

n

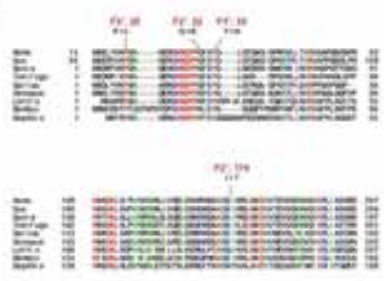

Figure 3. Position of the mutations in the ribonucleic acid and protein products.

A. Positions of mutations in conserved SRA secondary structures. Conserved SRA secondary structures (Helices H1-2 and H15-18) identified by Novikova et al (28) and corresponding to the regions containing the observed mutations are depicted (28). Nucleotides are numbered using the first human " $A$ " from the first AUG codon as 1. The exact location of the mutations observed in Family 1 ( $F 1^{*}$, 103), Family $2\left(F 2 *, 94\right.$ and 536), and Family $3\left(F 3^{*}, 59\right)$ are indicated. Please note that all mutations but $\mathrm{F} 1^{*}$ affect nucleotides involved in conserved helices and might contribute to their stability. Shown are Dot bracket notation (top) and Plain secondary (bottom) structures. Graph generated by The Vienna ribonucleic acid (RNA) website (http:// rna.tbi.univie.ac.at/cgi-bin/RNAfold.cgi).

B. Position of mutations in conserved SRAP protein sequences.

Two portions of the sequences of SRAP from Homo sapiens (NP_001030312.2, 236 aa), Susscrofa (XP_003124061.1, 280 aa), Daniorerio (NP_001002047.1, 210 aa), Takifugurubripes (XP_011609562.1, 264 aa), Gallus gallus (NP_001288615.1, 219 aa), Xenopuslaevi (NP_001107371.1, 227 aa), Lottiagigantea (XP_009055386.1, 279 aa), Bombyxmori (XP_004922978.1, 201 aa), and Daphnia pulex (EFX89230.1, 203 aa), which correspond to the region containing the mutations found in this study have been aligned. The numbers correspond to the positions of the side amino acids of the sequence shown. Amino acids identical, strongly similar, and weakly similar are colored in red, green, and blue, respectively. The top and bottom regions depicted correspond to the first and second phylogenetically conserved portion of SRAP, respectively (23). The exact location of the mutations observed in Family 1 ( $F 1^{*}, Y$ to $\left.N, 35\right)$, Family 2 (F2*, $\mathrm{Q}$ to $\mathrm{E}, 32$ and I to $\mathrm{T}, 179)$, and Family 3 (F3*, $\mathrm{P}$ to $\mathrm{L}, 20)$ are indicated. Please note that these mutations modify amino acids that are identical in all chordata 
that transfected cells express similar levels of endogenous SRAP and exogenous mutant proteins. We also checked that SRA-WT, an SRA-Y35N mutant protein, had similar localization

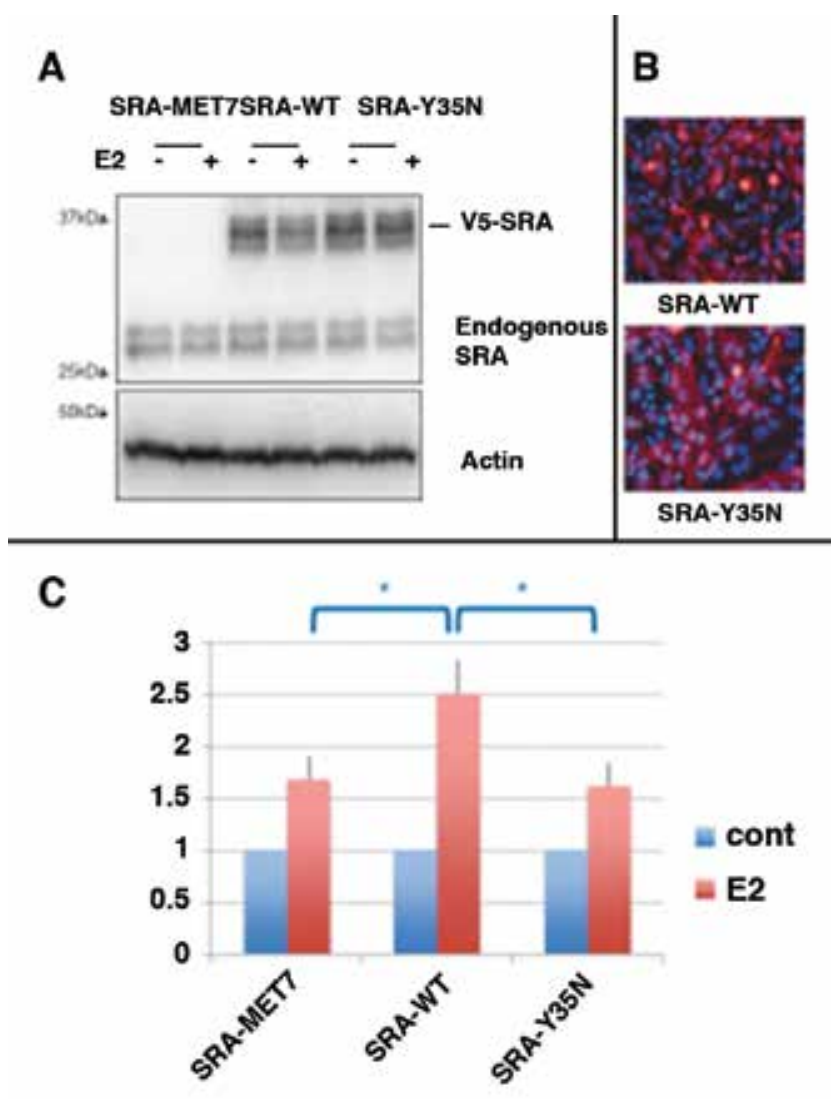

Figure 4. Functional analyses of SRA1 mutant p.Y35N

A) Levels of SRAP expression protein extracts of transfected HeLa cells. Equal volumes of luciferase assay extracts from HeLa cells transfected with Estrogen Receptor- $\alpha$ (ESR1ESR1) and PS2-ERE luciferase reporter plasmids, and either control (SRA-MET7), wildtype (SRA-WT), or mutant (SRA-Y35N) SRA plasmids, were subjected to western blot analysis using anti-SRAP (743, Bethyl Laboratories) and anti-Actin antibodies (Abcam). Shown is a representative blot displaying equal levels of exogenous V5-epitope tagged SRAP $(\sim 35 \mathrm{kDa})$ products in both SRA-WT and SRA-Y35N but not control SRA-MET7 transfected cell lysates.

B) Pancellular localization of wild-type versus Y35N SRAP. HeLa cells were transiently transfected with either V5-epitope tagged SRA-WT or SRA-Y35N constructs and exogenous SRAP (Red) expression was observed by indirect immunofluorescent microscopy using anti-V5 (Life Technologies) primary antibody followed by anti-MouseAlexa555 (Life Technologies). Cells were counterstained with Dapi to visualize nuclei (Blue)

C) SRA-Y35N mutation results in impaired estradiol induced ESR1 transactivation of PS2-ERE luciferase reporter. HeLa cells were cotransfected with Estrogen Receptor- $\alpha$ (ESR1), PS2-ERE luciferase reporter, and either control (SRA-MET7), wild-type (SRA-WT), or mutant (SRA-Y35N) SRA plasmids $24 \mathrm{~h}$ prior to being treated with estradiol (+E2) or ethanol (cont). Data were normalized as detailed in the Materials and Methods section. Error bars represent standard deviation for $n=4$. Unpaired 2 tailed student's t-test was performed to test for significant difference among different conditions (* ${ }^{*}$ represents $p<0.05)$
(Figure 4B), i.e. cytoplasmic and nuclear, as previously described $(13,14)$.

As shown in Figure 4, in the control SRA-MET7 and ESR1 co-transfected HeLa cells, estradiol treatment resulted in an approximate 1.6 fold increase in luciferase activity over that obtained from control transfected cells treated with ethanol vehicle alone (t-test, $\mathrm{p}<0.05$ ) (Figure $4 \mathrm{C}$, bars 1 vs 2). By comparison, co-transfection with SRA-WT resulted in a more pronounced and significant 2.5 fold increase in luciferase activity in the presence of estradiol (t-test, $p<0.01$ ) (compare bars 3 vs 4). These data are consistent with previously published results that indicate wild-type SRA to be an ESR1 co-activator (6). In contrast, SRA-Y35N did not increase the action of estradiol in this system, as indicated by similar luciferase activity in SRA-MET7 negative control and SRA-Y35N transfected cells (compare bars 2 and 6).

Overall, these data indicate that the mutant Y35N SRA is functionally different than the wild-type SRA and is unable to co-activate ER-alpha under these luciferase reporter assay conditions indicating a loss of function in this specific assay.

\section{Discussion}

In this article, we report three independent families in which affected siblings with inactivating mutations in SRA1 suffer from $\mathrm{IH}$. We identified and confirmed these mutations by a variety of genetic methods including candidate screening, genome-wide SNP genotyping and autozygosity mapping, targeted exome sequencing, and whole exome sequencing. Extreme rarity of these variants was confirmed not only in the international databases but also in in-house and national ones.

The products of this gene, SRA RNA and SRAP protein, define a very intriguing bi-faceted genetic system where both RNA and protein products of the same gene have the potential to play specific and sometimes overlapping roles in cell biology (15).

The steroid receptor RNA activator (SRA) was originally identified as a functional non-coding RNA involved in the regulation of gene expression by steroid receptors $(8,12,16)$. It is now established that this RNA forms complexes, through critical secondary structures and loops, with a wide range of molecules including, but not limited to, multiple nuclear receptors, nuclear receptors co-regulators, proteins involved in gene silencing and gene insulation $(8,11,17,18,19,20,21,22,23,24)$. Subsequently, some SRA transcripts were found to be able to encode for a protein, now referred to as the Steroid Receptor RNA Activator Protein (SRAP) $(13,25,26)$. This made SRA1 the first gene able to encode for both a functional RNA and a protein (26). SRAP, as its RNA counterpart, has now been known to positively regulate the activity of steroid receptor such as the androgen receptor (AR) and the estrogen receptor $(25,27)$. 
We showed in this study that while WT-SRA acted, as expected, as an ER-alpha co-activator in a reporter assay, the mutation identified in Family 1 patients elicited a significantly decreased estradiol dependent ER-alpha activity. Notably, mutations in this study are located, in the protein sequence, within the two SRAP domains highly conserved among chordate $(15,23)$. These mutations are also positioned in the Helix 1, 2, and 15 of the non-coding SRA sequence, which are highly conserved in all chordate (28). As outlined earlier, it has been shown that SRA conserved secondary structures were critical for its functional properties (12). Overall, the fact that the mutations identified here lay within both RNA and protein conserved regions emphasize the likelihood that they could have a profound effect on SRA and/or SRAP action, whatever the exact relevant mechanisms are involved.

$\mathrm{IHH}$ could be caused by defects in the hypothalamus and/or the pituitary. In both tissues, sex steroid receptors, ER-alfa and AR, are expressed. These receptors sense and accordingly respond to peripheral sex steroid levels in a negative feed-back pattern. Thus, inactivating mutations in SRA1, a known coactivator of ER-alfa (as once again shown in the control experiments in this study), should result in increased but not decreased gonadotropin levels. This would not be consistent with the phenotype of $\mathrm{IHH}$ seen in our patients. Indeed, in the rare cases of male and female patients who have inactivating ER-alfa mutations, there is a clear clinical picture of hypergonadotropic hypogonadism $(29,30)$. Therefore, inactivating SRA1 mutations in our patients in this study must have caused hypogonadotropic hypogonadism by a mechanism other than via a decreased ER-alfa coactivation either at the hypothalamic or the pituitary level. When we stimulated the proband in Family 1 with $\mathrm{GnRH}$ in an extended fashion, the patient did not show a noticeable LH response, suggesting that the response of the pituitary gland to $\mathrm{GnRH}$ is compromised, thus we focused on the pituitary as the site of dysfunction leading to $\mathrm{IHH}$ (31).

Vertebrate members of the nuclear receptor NR5A subfamily, which includes steroidogenic factor 1 (SF-1) and liver receptor homolog 1 (LRH-1), regulate crucial aspects of development, endocrine homeostasis, and metabolism. In the pituitary, both $\mathrm{LRH} 1$ and SF-1 regulate the expression of the gonadotropins $(32,33,34)$ and of the $\mathrm{GnRH}$ receptor $(32,35)$. Mice with pituitary-specific disruption of SF-1 have markedly diminished levels of pituitary gonadotropins modeling hypogonadotropic hypogonadism (36). DAX-1 (NROB 1), a close partner of SF-1, acts as an adaptor that recruits other factors, such as the nuclear receptor corepressors to SF-1. In humans, inactivation mutations of $D A X-1$ are well known to cause hypogonadotropic hypogonadism (37). Notably, the endogenous SRA is required for the synergistic enhancement of SF-1 transcriptional activity by Dax-1. Taken together, it appears that SRA1 regulates SF-1 target gene expression by functioning as a coactivator in association with Dax-1 (11). Thus, reduced SRA1 activity due to inactivating mutations found in this study would result in diminished SF-1/LRH-1 effect leading to $\mathrm{IHH}$, in parallel to the mechanism by which $\mathrm{IHH}$ is caused by inactivating $D A X-1$ mutations.

Interestingly, in one of the families (Family 3), we observed mutations in two genes, i.e. SRA1 and PNPLA6. Digenic inheritance is a well-established phenomenon of $\mathrm{IHH}$, accounting for about $10 \%$ of all cases $(38,39)$. With the increase in number of unbiased comprehensive genetic studies such as whole exome sequencing, it is now further appreciated that oligogenic inheritance is quite common in Mendelian disorders (40). Recently, a dedicated database for digenic inheritance has been established, in which $\mathrm{IHH}$ is listed along with other wellknown oligogenic phenotypes such as non-syndromic hearing impairment (41).

In digenic inheritance, gene pairs are associated with one another by sharing pathway membership in about $20 \%$ of the time (41). We recently described patients with Gordon-Holmes syndrome ( $\mathrm{HH}$ and cerebellar ataxia) due to inactivating PNPLA6 mutations (42). PNPLA6 encodes for neuropathy target esterase (NTE), a lysophospholipase that maintains intracellular phospholipid homeostasis by converting lysophosphatidylcholine to glycerophosphocholine (42). We also demonstrated that inhibition of NTE activity in the L $\beta T 2$ gonadotrope cell line, which represents the pituitary gonadotropes, diminished $\mathrm{LH}$ response to $\mathrm{GnRH}$ by impaired $\mathrm{LH}$ release from pituitary gonadotropes leading to $\mathrm{IHH}$. Thus, the sites of action of SRA1 and PNPLA6 seem to overlap at the pituitary gonadotropes, which suggests that dysfunction of these two gene variants potentialize or are additive to each other. Even more interestingly, there is ample evidence in the literature to show that phospholipids including certain species of lysophosphatidylcholine are ligands for SF-1/LRH-1, potentially placing two genes (i.e. SRA1 and PNPLA6) in the same pathway $(43,44)$. In fact, phospholipids may represent a potential link between metabolism and reproductive function (45). Although a pituitary site of action seems probable, a hypothalamic involvement cannot be ruled out as there are publications supporting this contention. Most notably, both $\mathrm{LRH}-1$ and DAX-1 (46) are expressed in the arcuate nucleus and $\mathrm{LRH}-1$ provides a stimulus for kisspeptin activation in the $\mathrm{GnRH}$ pulse generator (47).

As for the unusual clinical and laboratory features of these families, the proband in Family 2 and the younger brother (II4) in Family 3 had undescended testicles and micropenis in infancy suggesting a profound prenatal undervirilization due to a severe $\mathrm{IHH}$. But later, at a delayed age, they went through puberty with or without intervention. Spontaneous or induced regain of central gonadal function or reversibility is seen in about 10 percent of all $\mathrm{IHH}$ cases (48), even in the most severe cases of congenital IHH (49). In Family 3, the older sister (II1) appears to be unaffected despite carrying the same two variants as her affected brothers. Like her younger brother, she 
may have gone through spontaneous recovery. It should be noted however, that similar variability of phenotypes from $\mathrm{IHH}$ to delayed puberty to even normal timing in persons carrying the same genotype within the same family has been repeatedly observed $(50,51,52,53)$. Alternatively, a third mutated gene or a copy number variation among others could have provided an explanation for the genotype/phenotype discrepancy in this family, but we have not been able to find one.

Lastly, a global knock-out of SRA in the mouse has been recently reported. This model mouse protects against dietinduced obesity and improves whole body glucose homeostasis probably via its action as a PPARy coactivator. The SRA-/- mice appeared "normal" with no specific information regarding their reproductive function provided (54).

In conclusion, it is evident from the studies reported here that inactivating mutations of the SRA1 gene cause complete normosmic $\mathrm{IHH}$, hence pubertal failure in humans, and we would argue that proper function of SRA1 is a critical element of the central gonadal function in humans. It is tempting to speculate that SRA1, an intriguing gene whose products functioning both as a protein and a noncoding RNA, may in part account for the complexity, versatility, and elusiveness of the pubertal process, especially when one considers the fact that actions of nuclear receptor coregulators can spatially and temporally vary to become activators or repressors of the target nuclear receptors depending on the cellular and promoter context.

\section{Acknowledgment}

This work was supported by the Scientific and Technological Research Council of Turkey (TÜBITAK) (Project no: 113S962) and by the Çukurova University Scientific Research Projects. The Laboratory of EL is currently funded by the Canadian Breast Cancer Foundation.

We thank the Advanced Genomics and Bioinformatics Research Center (IGBAM) for checking the variant frequency in their in-house Turkish whole exome database at the TÜBITAKBILGEM.

The authors thank Dr. Sergio R. Ojeda, Dr. Alejandro Lomniczi, and Dr. Juan M. Castellano of OHSU Oregon National Primate Center for valuable discussions.

\section{Ethics}

Ethics Committee Approval: The Ethics Committee of the Çukurova University Faculty of Medicine approved, Informed Consent: Obtained from each participant or from the parents.

Peer-review: Internal peer-reviewed.

\section{Authorship Contributions}

Concept: Leman Damla Kotan, A. Kemal Topaloğlu, Etienne Leygue, Design: Leman Damla Kotan, A. Kemal Topaloğlu, Etienne Leygue, Data Collection and/or Processing: Charlton Cooper, Şükran Darcan, Samim Özen, Yi Yan, Fatih Gürbüz, Eda Mengen, Ihsan Turan, Ayça Ulubay, Gamze Akkuş, Bilgin
Yüksel, Analysis and/or Interpretation: lan M. Carr, Charlton Cooper, Mohammad K. Hamedani, Literature Research: Leman Damla Kotan, Fatih Gürbüz, Eda Mengen, Ihsan Turan, Writing: Leman Damla Kotan, A. Kemal Topaloğlu, Etienne Leygue.

Financial Disclosure: The authors declared that this study received no financial support.

\section{References}

1. Semple RK, Topaloglu AK. The recent genetics of hypogonadotrophic hypogonadism - novel insights and new questions. Clin Endocrinol (Oxf) 2010;72:427-435. Epub 2009 Aug 29

2. Topaloglu AK, Reimann F, Guclu M, Yalin AS, Kotan LD, Porter KM, Serin A, Mungan NO, Cook JR, Ozbek MN, Imamoglu S, Akalin NS, Yuksel B, O'Rahilly S, Semple RK. TAC3 and TACR3 mutations in familial hypogonadotropic hypogonadism reveal a key role for Neurokinin B in the central control of reproduction. Nat Genet 2009;41:354-358. Epub 2008 Dec 11

3. Topaloglu AK, Tello JA, Kotan LD, Ozbek MN, Yilmaz MB, Erdogan S, Gurbuz F, Temiz F, Millar RP, Yuksel B. Inactivating KISS1 mutation and hypogonadotropic hypogonadism. N Engl J Med 2012;366:629-635

4. Lehman MN, Coolen LM, Goodman RL. Minireview: kisspeptin/neurokinin B/dynorphin (KNDy) cells of the arcuate nucleus: a central node in the control of gonadotropinreleasing hormone secretion. Endocrinology 2010;151:34793489. Epub 2010 May 25

5. Topaloglu AK, Kotan LD. Genetics of hypogonadotropic hypogonadism. Endocr Dev 2016;29:36-49. Epub 2015 Dec 17

6. Chooniedass-Kothari S, Vincett D, Yan Y, Cooper C, Hamedani M, Myal Y, Leygue E. The protein encoded by the functional steroid receptor RNA activator is a new modulator of ER alpha transcriptional activity. Febs Lett 2010;584:1174-1180. Epub 2010 Feb 11

7. Yan Y, Skliris GP, Penner C, Chooniedass-Kothari S, Cooper C, Nugent Z, Blanchard A, Watson PH, Myal Y, Murphy LC, Leygue E. Steroid Receptor RNA Activator Protein (SRAP): a potential new prognostic marker for estrogen receptorpositive/node-negative/younger breast cancer patients. Breast Cancer Res 2009;11:67.

8. Lanz RB, McKenna NJ, Onate SA, Albrecht U, Wong J, Tsai SY, Tsai MJ, O'Malley BW. A steroid receptor coactivator, SRA, functions as an RNA and is present in an SRC-1 complex. Cell 1999;97:17-27.

9. Deblois G, Giguere V. Ligand-independent coactivation of ERalpha AF-1 by steroid receptor RNA activator (SRA) via MAPK activation. J Steroid Biochem Mol Bio 2003;85:123131.

10. Klinge CM, Jernigan SC, Mattingly KA, Risinger KE, Zhang $J$. Estrogen response element-dependent regulation of transcriptional activation of estrogen receptors alpha and beta by coactivators and corepressors. J Mol Endocrinol 2004;33:387-410.

11. Xu B, Yang WH, Gerin I, Hu CD, Hammer GD, Koenig RJ. Dax-1 and steroid receptor RNA activator (SRA) function as transcriptional coactivators for steroidogenic factor 1 in steroidogenesis. Mol Cell Biol 2009;29:1719-1734. Epub 2009 Feb 2 
12. Lanz RB, Razani B, Goldberg AD, O'Malley BW. Distinct RNA motifs are important for coactivation of steroid hormone receptors by steroid receptor RNA activator (SRA). Proc Natl Acad Sci USA 2002;99:16081-16086. Epub 2002 Nov 20

13. Emberley E, Huang GJ, Hamedani MK, Czosnek A, Ali D, Grolla A, Lu B, Watson PH, Murphy LC, Leygue E. Identification of new human coding steroid receptor RNA activator isoforms. Biochem Biophys Res Commun 2003;301:509-515.

14. McKay DB, Xi L, Barthel KK, Cech TR. Structure and function of steroid receptor RNA activator protein, the proposed partner of SRA noncoding RNA. J Mol Biol 2014;426:17661785. Epub 2014 Jan 30

15. Cooper C, Vincett D, Yan Y, Hamedani MK, Myal Y, Leygue E. Steroid Receptor RNA Activator bi-faceted genetic system: Heads or Tails? Biochimie 2011;93:1973-1980. Epub 2011 Jul 12

16. Lanz RB, Chua SS, Barron N, Söder BM, DeMayo F, O'Malley BW. Steroid receptor RNA activator stimulates proliferation as well as apoptosis in vivo. Mol Cell Biol 2003;23:7163-7176.

17. Liu S, Xu R, Gerin I, Cawthorn WP, Macdougald OA, Chen XW, Saltiel AR, Koenig RJ, Xu B. SRA regulates adipogenesis by modulating p38/JNK phosphorylation and stimulating insulin receptor gene expression and downstream signaling. PLoS One 2014;9:95416.

18. Redfern AD, Colley SM, Beveridge DJ, Ikeda N, Epis MR, Li X, Foulds CE, Stuart LM, Barker A, Russell VJ, Ramsay K, Kobelke SJ, Li X, Hatchell EC, Payne C, Giles KM, Messineo A, Gatignol A, Lanz RB, O'Malley BW, Leedman PJ. RNAinduced silencing complex (RISC) Proteins PACT, TRBP, and Dicer are SRA binding nuclear receptor coregulators. Proc Natl Acad Sci U S A 2013;110:6536-6541. Epub 2013 Apr 2

19. Beato M, Vicent GP. A new role for an old player: steroid receptor RNA Activator (SRA) represses hormone inducible genes. Transcription 2013:4:167-171. Epub 2013 Jul 1

20. Yao H, Brick K, Evrard Y, Xiao T, Camerini-Otero RD, Felsenfeld G. Mediation of CTCF transcriptional insulation by DEAD-box RNA-binding protein p68 and steroid receptor RNA activator SRA. Genes Dev 2010;24:2543-2555. Epub 2010 Oct 21

21. Xu B, Gerin I, Miao H, Vu-Phan D, Johnson CN, Xu R, Chen $X W$, Cawthorn WP, MacDougald OA, Koenig RJ. Multiple roles for the non-coding RNA SRA in regulation of adipogenesis and insulin sensitivity. PLoS One 2010;5:14199.

22. Kelly VR, Xu B, Kuick R, Koenig RJ, Hammer GD. Dax1 up-regulates Oct4 expression in mouse embryonic stem cells via LRH-1 and SRA. Mol Endocrinol 2010;24:22812291. Epub 2010 Oct 13

23. Leygue E. Steroid receptor RNA activator (SRA1): unusual bifaceted gene products with suspected relevance to breast cancer. Nucl Recept Signal 2007;5:006.

24. Vicent GP, Nacht AS, Zaurin R, Font-Mateu J, Soronellas D, Le Dily F, Reyes D, Beato M. Unliganded progesterone receptormediated targeting of an RNA-containing repressive complex silences a subset of hormone-inducible genes. Genes Dev 2013;27:1179-1197.

25. Kawashima H, Takano H, Sugita S, Takahara $Y$, Sugimura $K$, Nakatani T. A novel steroid receptor co-activator protein (SRAP) as an alternative form of steroid receptor RNAactivator gene: expression in prostate cancer cells and enhancement of androgen receptor activity. Biochem J 2003;369:163-171.
26. Chooniedass-Kothari S, Emberley E, Hamedani MK, Troup S, Wang X, Czosnek A, Hube F, Mutawe M, Watson PH, Leygue $E$. The steroid receptor RNA activator is the first functional RNA encoding a protein. FEBS Lett 2004;566:43-47.

27. Chooniedass-Kothari S, Vincett D, Yan Y, Cooper C, Hamedani MK, Myal Y, Leygue E. The protein encoded by the functional steroid receptor RNA activator is a new modulator of ER alpha transcriptional activity. FEBS Lett 2010;584:1174-1180. Epub 2010 Feb 11

28. Novikova IV, Hennelly SP, Tung CS, Sanbonmatsu KY. Rise of the RNA machines: exploring the structure of long noncoding RNAs. J Mol Biol 2013;425:3731-3746. Epub 2013 Mar 4

29. Quaynor SD, Stradtman EW Jr, Kim HG, Shen Y, Chorich LP, Schreihofer DA, Layman LC. Delayed puberty and estrogen resistance in a woman with estrogen receptor alpha variant. N Engl J Med 2013;369:164-171

30. Smith EP, Boyd J, Frank GR, Takahashi H, Cohen RM, Specker B, Williams TC, Lubahn DB, Korach KS. Estrogen resistance caused by a mutation in the estrogen-receptor gene in a man. N Engl J Med 1994;331:1056-1061.

31. Seminara SB, Acierno JS Jr, Abdulwahid NA, Crowley WF Jr, Margolin DH. Hypogonadotropic hypogonadism and cerebellar ataxia: detailed phenotypic characterization of a large, extended kindred. J Clin Endocrinol Metab 2002;87:1607-1612.

32. Zheng W, Yang J, Jiang Q, He Z, Halvorson LM. Liver receptor homologue-1 regulates gonadotrope function. J Mol Endocrinol 2007;38:207-219.

33. Barnhart KM, Mellon PL. The orphan nuclear receptor, steroidogenic factor-1, regulates the glycoprotein hormone alpha-subunit gene in pituitary gonadotropes. Mol Endocrinol 1994:8:878-885.

34. Ingraham HA, Lala DS, Ikeda Y, Luo X, Shen WH, Nachtigal MW, Abbud R, Nilson JH, Parker KL. The nuclear receptor steroidogenic factor 1 acts at multiple levels of the reproductive axis. Genes Dev 1994;8:2302-2312.

35. Ngan ES, Cheng PK, Leung PC, Chow BK. Steroidogenic factor-1 interacts with a gonadotrope-specific element within the first exon of the human gonadotropin-releasing hormone receptor gene to mediate gonadotrope-specific expression. Endocrinology 1999;140:2452-2462.

36. Zhao X, Patton JR, Davis SL, Florence B, Ames SJ, Spanjaard RA. Regulation of nuclear receptor activity by a pseudouridine synthase through posttranscriptional modification of steroid receptor RNA activator. Mol Cell 2004;15:549-558.

37. Schimmer BP, White PC. Minireview: steroidogenic factor 1 : its roles in differentiation, development, and disease. Mol Endocrinol 2010;24:1322-1337. Epub 2010 Mar 4

38. Quaynor SD, Kim HG, Cappello EM, Williams T, Chorich LP, Bick DP, Sherins RJ, Layman LC. The prevalence of digenic mutations in patients with normosmic hypogonadotropic hypogonadism and Kallmann syndrome. Fertil Steril 2011;96:1424-1430. Epub 2011 Oct 28

39. Pitteloud N, Quinton R, Pearce $S$, Raivio T, Acierno J, Dwyer A, Plummer L, Hughes V, Seminara S, Cheng YZ, Li WP, Maccoll G, Eliseenkova AV, Olsen SK, Ibrahimi OA, Hayes FJ, Boepple P, Hall JE, Bouloux P, Mohammadi M,Crowley W. Digenic mutations account for variable phenotypes in 
idiopathic hypogonadotropic hypogonadism. J Clin Invest 2007;117:457-463. Epub 2007 Jan 18

40. Chong JX, Buckingham KJ, Jhangiani SN, Boehm C, Sobreira N, Smith JD, Harrell TM, McMillin MJ, Wiszniewski W, Gambin T, Coban Akdemir ZH, Doheny K, Scott AF, Avramopoulos D, Chakravarti A, Hoover-Fong $J$, Mathews D, Witmer PD, Ling H, Hetrick K, Watkins $L$, Patterson KE, Reinier F, Blue E, Muzny D, Kircher M, Bilguvar K, López-Giráldez F, Sutton VR, Tabor HK, Leal SM, Gunel M, Mane S, Gibbs RA, Boerwinkle E, Hamosh A, Shendure J, Lupski JR, Lifton RP, Valle D, Nickerson DA; Centers for Mendelian Genomics, Bamshad MJ. The genetic basis of mendelian phenotypes: discoveries, challenges, and opportunities. Am J Hum Genet 2015; 97:199-215. Epub 2015 Jul 9

41. Gazzo AM, Daneels D, Cilia E, Bonduelle M, Abramowicz M, Van Dooren S, Smits G, Lenaerts T. DIDA: A curated and annotated digenic diseases database. Nucleic Acids Res 2016;44:900-907. Epub 2015 Oct 19

42. Topaloglu AK, Lomniczi A, Kretzschmar D, Dissen GA, Kotan LD, McArdle CA, Koc AF, Hamel BC, Guclu M, Papatya ED, Eren E, Mengen E, Gurbuz F, Cook M, Castellano JM, Kekil MB, Mungan NO, Yuksel B, Ojeda SR. Loss-of-function mutations in PNPLA6 encoding neuropathy target esterase underlie pubertal failure and neurological deficits in Gordon Holmes syndrome. J Clin Endocrinol Metab 2014;99:20672075. Epub 2014 Jul 17

43. Krylova IN, Sablin EP, Moore J, Xu RX, Waitt GM, MacKay JA, Juzumiene D, Bynum JM, Madauss K, Montana V, Lebedeva L, Suzawa M, Williams JD, Williams SP, Guy RK, Thornton JW, Fletterick RJ, Willson TM, Ingraham HA. Structural analyses reveal phosphatidyl inositols as ligands for the NR5 orphan receptors SF-1 and LRH-1. Cell 2005;120:343-355.

44. Lee JM, Lee YK, Mamrosh JL, Busby SA, Griffin PR, Pathak MC, Ortlund EA, Moore DD. A nuclear-receptor-dependent phosphatidylcholine pathway with antidiabetic effects. Nature 2011:474:506-510.

45. Sablin EP, Blind RD, Krylova IN, Ingraham JG, Cai F, Williams JD, Fletterick RJ, Ingraham HA. Structure of SF-1 bound by different phospholipids: evidence for regulatory ligands. Mol Endocrinol 2009;23:25-34. Epub 2008 Nov 6

46. Gofflot F, Chartoire N, Vasseur L, Heikkinen S, Dembele D, Le Merrer J, Auwerx J. Systematic gene expression mapping clusters nuclear receptors according to their function in the brain. Cell 2007;131:405-418.

47. Atkin SD, Owen BM, Bookout AL, Cravo RM, Lee C, Elias CF, Elmquist JK, Kliewer SA, Mangelsdorf DJ. Nuclear receptor
$\mathrm{LRH}-1$ induces the reproductive neuropeptide kisspeptin in the hypothalamus. Mol Endocrinol 2013;27:598-605. Epub 2013 Mar 15

48. Raivio T, Falardeau J, Dwyer A, Quinton R, Hayes FJ, Hughes VA, Cole LW, Pearce SH, Lee H, Boepple P, Crowley WF $\mathrm{Jr}$, Pitteloud N. Reversal of idiopathic hypogonadotropic hypogonadism. N Engl J Med 2007;357:863-873.

49. Gianetti $E$, Tusset $C$, Noel SD, Au MG, Dwyer AA, Hughes VA, Abreu AP, Carroll J, Trarbach E, Silveira LF, Costa EM, de Mendonca $B B$, de Castro M, Lofrano A, Hall JE, Bolu E, Ozata M, Quinton R, Amory JK, Stewart SE, Arlt W, Cole TR, Crowley WF, Kaiser UB, Latronico AC, Seminara SB. TAC3/TACR3 mutations reveal preferential activation of gonadotropin-releasing hormone release by neurokinin B in neonatal life followed by reversal in adulthood. J Clin Endocrinol Metab 2010;95:2857-2867. Epub 2010 Mar 23

50. Zhu J, Choa RE, Guo MH, Plummer L, Buck C, Palmert MR, Hirschhorn JN, Seminara SB, Chan YM. A shared genetic basis for self-limited delayed puberty and idiopathic hypogonadotropic hypogonadism. J Clin Endocrinol Metab 2015;100:646-654. Epub 2015 Jan 30

51. Sykiotis GP, Plummer L, Hughes VA, Au M, Durrani S, NayakYoung S, Dwyer AA, Quinton R, Hall JE, Gusella JF, Seminara SB, Crowley WF Jr, Pitteloud N. Oligogenic basis of isolated gonadotropin-releasing hormone deficiency. Proc Natl Acad Sci USA 2010;107:15140-15144. Epub 2010 Aug 9

52. Sarfati J, Guiochon-Mantel A, Rondard P, Arnulf I, GarciaPiñero A, Wolczynski S, Brailly-Tabard S, Bidet M, RamosArroyo M, Mathieu M, Lienhardt-Roussie A, Morgan G, Turki Z, Bremont C, Lespinasse J, Du Boullay H, Chabbert-Buffet N, Jacquemont S, Reach G, De Talence N, Tonella P, Conrad B, Despert F, Delobel B, Brue T, Bouvattier C, Cabrol S, Pugeat M, Murat A, Bouchard P, Hardelin JP, Dodé C, Young J. A comparative phenotypic study of kallmann syndrome patients carrying monoallelic and biallelic mutations in the prokineticin 2 or prokineticin receptor 2 genes. J Clin Endocrinol Metab 2010;95:659-669. Epub 2009 Dec 18

53. Boehm U, Bouloux PM, Dattani MT, de Roux N, Dode C, Dunkel L, Dwyer AA, Giacobini P, Hardelin JP, Juul A, Maghnie M, Pitteloud N, Prevot V, Raivio T, Tena-Sempere M, Quinton R, Young J. Expert consensus document: European Consensus Statement on congenital hypogonadotropic hypogonadism--pathogenesis, diagnosis and treatment. Nat Rev Endocrinol 2015; 11:547-564. Epub 2015 Jul 21

54. Liu S, Sheng L, Miao H, Saunders TL, MacDougald OA, Koenig RJ, Xu B. SRA gene knockout protects against dietinduced obesity and improves glucose tolerance. J Biol Chem 2014;289:13000-13009. Epub 2014 Mar 27 